\title{
Reforma e profecia: a ação do arcebispo de Goa e místico D. Gaspar de Leão
}

\author{
Patricia Souza de FARIA ${ }^{\bullet}$
}

\begin{abstract}
Resumo: Estudo sobre o primeiro arcebispo de Goa, D. Gaspar de Leão (1560 - 1576), que desempenhou um papel significativo no processo de cristianização das terras asiáticas controladas pelos portugueses. Durante o período em que D. Gaspar administrou o Arcebispado de Goa, o Tribunal do Santo Ofício de Goa foi criado (único tribunal inquisitorial instituído em um domínio luso), celebrou-se o primeiro Concílio Provincial na região (em 1567) e foram redigidas as Constituições do Arcebispado de Goa, em consonância com as determinações do Concílio de Trento incentivadoras da realização de sínodos provinciais e da projeção dos bispos na condução da reforma espiritual do clero e dos fiéis. D. Gaspar foi marcado por correntes místicas cristãs e publicou obras sobre a "via unitiva" ou a expansão do Evangelho, repletas de vaticínios sobre a conversão definitiva de muçulmanos e de judeus.
\end{abstract}

Palavras-chave: Império Português; Índia; Catolicismo.

Analisaremos a atuação do primeiro Arcebispo de Goa, D. Gaspar de Leão (1560-1576), que partiu para a Índia em 1560, na companhia dos primeiros inquisidores que estabeleceram o Tribunal do Santo Ofício de Goa, após a realização de uma devassa eclesiástica em 1557 contra os cristãos-novos acusados de "judaizar" nas terras de Goa e de Cochim. D. Gaspar atingiu o solo indiano quando a busca por uma maciça cristianização de Goa completava aproximadamente duas décadas, pois em torno

\footnotetext{
- Professora Doutoura - Departamento de História - Universidade Federal de Viçosa - UFV - 36.570-000 - Viçosa - MG - Brasil. E-mail: patricia.faria@ufv.br
} 
de 1540 foram destruídos templos hindus e mesquitas, os convertidos ao catolicismo recebiam privilégios e aqueles que rejeitavam o batismo poderiam ser expulsos da região.

D. Gaspar deveria tentar conduzir o seu vasto arcebispado a partir de Goa, sede do poder civil e eclesiástico do Estado da Índia - designação usada para indicar as conquistas e territórios portugueses localizados de forma esparsa desde a costa oriental africana até o Extremo-Oriente. Os diferentes domínios, conquistas e fortalezas portuguesas do Estado da Índia formavam uma "rede", um sistema de comunicação entre vários espaços (THOMAZ, 1994: 206). Além da descontinuidade espacial, o Estado da Índia caracterizou-se pela heterogeneidade das instituições, pois, a Coroa portuguesa reivindicou graus variáveis de autoridade sobre estes espaços, tais como a soberania sobre os mares, o monopólio de determinadas atividades comerciais ou o exercício da autoridade em regiões anexadas e dotadas de oficiais régios (NEWITT, 2001). Destaca-se a instabilidade nestes territórios em virtude de ameaças como o cerco de Diu - ocorrido em 1538, pelo sultão do Guzerate e em 1546, pelo rei de Cambaia - e o de Malaca, imposto por reis mouros de Java e da península malaia em 1551 (DORÉ, 2002: 321).

Goa tornou-se um núcleo urbano de importância política e também eclesiástica a partir da "segunda capitalização" ocorrida em 1534 com a instalação da diocese e, em 1557, da diocese metropolitana e do arcebispo em Goa (SANTOS, 1999). $\mathrm{Na}$ tentativa de implantar a ortodoxia católica em Goa foram adotadas medidas rigorosas (como a atividade inquisitorial, a destruição de templos indianos, a expulsão de adeptos de crenças que não fossem cristãs) ou mecanismos persuasivos, utilizados em busca da consolidação do cristianismo em uma região localizada entre domínios muçulmanos, onde também conviviam "hindus" e também cristãos-novos acusados de retornar às práticas e crenças judaicas. A produção de literatura edificante ou de textos para convencimento da suposta superioridade do catolicismo encaixava-se na segunda modalidade, persuasiva. D. Gaspar de Leão dedicou-se às duas 
modalidades, pois agiu com austeridade como Arcebispo e foi autor de textos confeccionados na imprensa de Goa, onde procurou atingir conversos judaizantes que viviam na Índia e persuadir os mouros sobre o fim iminente do islamismo, em tom escatológico.

Na imprensa de Goa, foi publicada em 1565 a tradução portuguesa de duas obras latinas de Jerônimo de Santa Fé - Ad convincendum perfidiam judaeroum e De judaicis erronibus ex Talmud, isto é, Prova da perfídia dos judeus e Erros dos judeus tirados do Talmude - realizada por D. Gaspar de Leão, acompanhada de carta apostólica escrita pelo arcebispo. Em 1573, foi publicada em Goa a obra Desengano de perdidos, em que D. Gaspar anunciou a total destruição dos mouros, conforme uma interpretação do livro de Apocalipse.

Esperamos demonstrar como D. Gaspar de Leão conduziu o Arcebispado de Goa inspirado nos desafios à fé cristã que, acreditava, assolavam o reino de Portugal e a Europa católica. Por esta razão, D. Gaspar mostrou-se muito preocupado com os históricos "inimigos" da fé católica que habitaram a Península Ibérica, pois em Goa se dedicou à escrita de obras de polêmica antijudaica e anti-islâmica. A inspiração para lidar com as dificuldades ligadas à consolidação do catolicismo no Oriente provinha de correntes reformistas que precederam o Concílio de Trento, especialmente as vertentes místicas, que preconizavam a via unitiva, uma via do coração para atingir um alto nível espiritual, embebida no franciscanismo e em premonições apocalípticas. Mas as orientações pós-tridentinas também reverberaram quando administrou o Arcebispado de Goa, ao dilatar a influência dos poderes episcopais - instância essencial na reforma católica após o Concílio de Trento.

\section{O poder episcopal e a cristianização de Goa no século XVI}

Nos anos iniciais da presença portuguesa na Índia, foi tolerada a convivência entre cristãos e povos que professassem outros credos, pois D. Manuel admitia súditos seguidores de 
outras crenças (RUSSELL-WOOD, 1998; COSTA, 2000). Porém, a partir do reinado de D. João III, foram estabelecidos dispositivos para extirpar as crenças não-cristãs de Goa e favorecer (com a oferta de cargos no Estado da Índia ou demais privilégios) aqueles que se convertessem ao catolicismo. Em Goa, foram estimuladas as práticas assistenciais, o ensino da doutrina cristã, a pregação pública, a confissão e houve o estabelecimento da Inquisição. As rendas das terras que pertenciam aos pagodes - templos não-cristãos da Índia que foram destruídos - foram transferidas para sustentar o culto católico e entregues à Confraria da Conversão da Fé ${ }^{1}$, fundada em 1541 para promover a conversão e assistir os novos convertidos, além de ter sido criado um seminário dedicado inicialmente aos convertidos locais (o Seminário da Santa Fé), cuja administração foi inicialmente oferecida aos franciscanos, mas foi assumida pelos jesuítas, que chegaram à Índia em 1542 (MENDONÇA, 2002: 342).

Estas medidas indicavam o desenvolvimento do "disciplinamento social", que consistia na estratégia de modelar os padrões de comportamento, ao incutir crenças e promover hábitos considerados cristãos, durante a Idade Moderna (PALOMO, 1997). Destacamos o papel desempenhado pelos poderes episcopais nesse processo de "disciplinamento social" e cristianização.

O bispado de Goa, instituído em 1534, tinha jurisdição sobre os domínios do Estado da Índia, ou seja, da costa oriental africana ao Extremo-Oriente. Em 1557, a diocese de Goa foi elevada à condição de Arcebispado e os domínios geográficos sobre sua administração foram desmembrados em decorrência da criação de duas novas dioceses sufragâneas: a de Cochim e a de Malaca. A partir de 1557, o arcebispo de Goa obteve jurisdição ordinária sobre as possessões portuguesas de Goa, Damão e Diu, regiões onde o Padroado português estabeleceu paróquias; sobre as missões fundadas no Concão e em Canará (sul e leste de Goa); sobre as igrejas construídas no âmbito do padroado, nas regiões ao norte de Goa, como Baçaim, Bombaim e Salsete (COUTINHO, 1958; ALDEN, 1996). 
Gaspar de Leão recusou o cargo de arcebispo de Goa sob a alegação de desejar se dedicar à vida contemplativa. Porém, o cardeal D. Henrique não aceitou a recusa e, através do embaixador Lourenço Pires de Távora, dirigiu-se ao Papa para forçar o prelado a aceitar a incumbência (ARIENZO, 1987). Após a ordem do pontífice, Gaspar de Leão partiu para o Oriente em 1560.

Quando D. Gaspar chegou à Índia em 1560, já vigoravam medidas e existiam instituições destinadas ao "disciplinamento social" dos domínios portugueses do Estado da Índia. Todavia, foi durante o período em que D. Gaspar administrou o Arcebispado de Goa que foi criado o Tribunal do Santo Ofício (1560) e celebrado o primeiro Concílio Provincial de Goa (1567), como trataremos adiante.

Para Ricardo Ventura, o contexto da montagem da estrutura eclesiástica em Goa e dos intensos esforços de cristianização dos povos locais através dos dispositivos mencionados tornava necessária a delegação de poderes para alguém responsável pelas questões religiosas e de consciência, sem que fosse preciso esperar o envio de consultas e a morosidade das respostas oriundas do reino de Portugal. Para Ventura, a escolha recairia em personalidade que fosse dotada de ampla experiência eclesiástica, um canonista ou teólogo com habilidade na área de administração episcopal, que a Coroa confiasse e que fosse um zeloso defensor da ortodoxia católica, obediente ao espírito da reforma tridentina. Esta personalidade seria Gaspar de Leão, que nasceu em Lagos, no Algarves, formou-se em Direito Canônico em 1536 pela Universidade de Salamanca; dois anos depois, tornou-se capelão e pregador do Cardeal Infante D. Henrique. Em 1551, tornou-se cônego da catedral de Évora, em 1559, quando recebeu a nomeação de arcebispo de Goa, exercia o cargo de arcediago do báculo e esmoler-mor do Cardeal D. Henrique (VENTURA, 2004: 505-518).

As medidas adotadas durante a atuação de D. Gaspar indicavam a intenção de estimular o recrudescimento da reforma moral do clero e do disciplinamento social dos católicos que viviam nos domínios sob a administração do Arcebispado de 
Goa, processo que havia iniciado há algumas décadas. Favoreceu o controle sobre os fiéis através das redes de paróquias e destacou a importância dos bispos, conforme as determinações do Concílio de Trento, que em muitos aspectos repetiu recomendações apresentadas em fases anteriores de reforma da Igreja (VENARD, 1992: 245). O Concílio de Trento estimulou a realização de sínodos episcopais, o que iria reverberar em Goa por ocasião dos Concílios Provinciais, sendo o primeiro realizado em 1567, durante a atividade do Arcebispo D. Gaspar.

\section{Gaspar de Leão e o Primeiro Concílio Provincial de Goa}

O Concílio de Trento orientou os bispos no sentido de se reunirem em sínodos episcopais e, com base nas discussões travadas nesses encontros, estabelecer constituições relacionadas, no âmbito doutrinário, aos sacramentos, ao ritual religioso, às tarefas e responsabilidades do clero, à administração do patrimônio e da justiça, aos pecados e desvios. Dentre as reuniões ocorridas em todo império, as reuniões episcopais de Goa foram as que mais se destacaram. Os Concílios Provinciais de Goa ocorreram nos anos 1567, 1575, 1585, 1592 e 1606 (BOSCHI, 1998: 437).

O primeiro Concílio Provincial de Goa ocorreu durante o vice-reinado de $\mathrm{D}$. Antão de Noronha, quando os clérigos se reuniram na Sé de Goa, com a presença de D. Gaspar de Leão (que presidiu o Concílio), Jorge Themudo (bispo de Cochim), Manoel Coutinho (administrador de Moçambique), Vicente Viegas (procurador do bispo de Malaca, D. Jorge), os superiores da Companhia de Jesus, da Ordem de São Domingos e de São Francisco, demais doutores em teologia, direito canônico e leis. O propósito declarado pelos clérigos para realização do Primeiro Concílio Provincial de Goa foi "comunicar a sua luz divina e verdade evangélica às nações da India Oriental, que tantos anos havia que estavam sujeitas ao império do príncipe das trevas". A leitura dos decretos instituídos em 1567 revela que existiam dois 
objetivos gerais que esperavam ser alcançados: aumentar o número de católicos existentes na Índia e disciplinar o comportamento do clero. Foram aprovados quarenta e sete decretos de interesse geral (Ação $2^{\mathrm{a}}$ ), trinta e cinco sobre a reforma dos assuntos eclesiásticos (Ação $3^{a}$ ) e trinta e três sobre a reforma moral (Ação $\left.3^{\mathrm{a}}\right)^{2}$.

Destaca-se a proibição do uso da força em busca da realização de batismos, pois a recomendação era oferecer vantagens àqueles que se convertessem à fé católica, como o favorecimento no arrendamento de aldeias, a concessão de liberdade aos escravos que se tornassem cristãos e possuíssem um senhor gentio. Antes de receber o batismo, os neófitos deveriam ser instruídos nos "artigos da fé, e mandamentos da ley", conforme a capacidade de cada um. Aos judeus, mouros estrangeiros e iogues, o batismo só deveria ser concedido depois de três meses, contados a partir do momento em que solicitaram o batismo, pois era alegado que costumavam retroceder, mas não era exigido o mesmo período para o batismo de gentios e mouros naturais (decreto $37^{\circ}, 2^{\mathrm{a}}$ ação).

Contudo, a proibição do uso da força não impediu o recurso a medidas que reprimiriam o paganismo, como a obrigação de ouvir a prédica contra as crenças não-cristãs (decreto V), o recurso à expulsão de pregadores mouros e hindus (decreto VI), a destruição de mesquitas e livros islâmicos (decreto IX), a proibição do sati (suicídio ritual da viúva indiana que se lançava na pira funerária do marido defunto) e do uso do cordão que os membros da casta brâmane portavam, além de outras interdições (ARANHA, 2006: 118-147). Os órfãos seriam retirados da tutela de parentes gentios e entregues aos cuidados de um cristão para "aprenderem bons costumes". As referências hierofânicas deveriam ser transformadas, pois os muçulmanos de Ormuz foram proibidos de observar a sexta-feira como dia religioso (decreto $30^{\circ}, 2^{a}$ seção) e os "infiéis" que habitavam os domínios portugueses deveriam frequentar as missas de domingos e as festas religiosas do calendário católico (decreto $31^{\circ}, 2^{a}$ seção). A dinâmica das sociabilidades locais deveria ser perturbada, pois as amizades íntimas entre um cristão e um 
"infiel" eram vistas com suspeita (decreto $24^{\circ}, 2^{\mathrm{a}}$ ação); as "mulheres erradas" deveriam viver separadas das mulheres cristãs (decreto $7^{\circ}, 4^{\mathrm{a}}$ seção).

Em 1568, foram aprovadas as Constituições do Arcebispado de Goa, examinadas no $1^{\circ}$ Concílio Provincial de $\mathrm{Goa}^{3}$. As Constituições do Arcebispado de Goa apresentavam as determinações acerca do modo em que deviam ser ministrados os sacramentos, quem teria competência para ministrá-los, quem poderia recebê-los e as penalidades para aqueles que deixaram de ser sacramentados. As Constituições trataram das procissões (Tít. 17) que ocorreriam nas áreas do Arcebispado de Goa, dos enterros e das missas de defuntos (Tít.18), das confrarias (Tít.19), dos ornamentos das igrejas (Tít.21), dos seus bens, rendas e foros (Tít. 22 a 24), dos bens dos eclesiásticos que morrem sem fazer testamento (Tít. 25) e da aplicação da excomunhão (Tít.27).

\section{Querelas e afinidades: o arcebispo e as ordens religiosas}

Até o momento, ressaltamos o papel desempenhado pelos poderes episcopais em busca da difusão de valores e comportamentos cristãos em Goa, mas não deve ser negligenciada a atividade exercida pelos membros do clero regular. Trataremos das relações estabelecidas entre o arcebispo D. Gaspar de Leão e as duas principais ordens religiosas que atuaram em Goa: a Ordem de São Francisco e a Companhia de Jesus.

Os franciscanos foram os primeiros membros do clero regular que chegaram à Índia no contexto da expansão portuguesa (em 1500), fixando-se na região a partir de 1517. Os jesuítas chegaram em 1542 sob a liderança de Francisco Xavier. Contudo, D. Gaspar proibiu os batismos em massa efetuados pelos jesuítas, criticou a pompa destes batismos, alegando que teriam perdido a humildade dos primeiros padres ${ }^{4}$. $O$ jesuíta Luís Fróis escreveu em 1561 sobre o assunto: 
Depois que desse Reino veo [...] o Senhor Arcebispo de Goa, Dom Gaspar, como elle seya pastor destas almas e mais propriamente lhe compitise por razão de seu ofitio a obrigação de proseder nesta obra que se tinha comesada, quis ele tomar o asumpto e proteição della, encarregando-se de fazer os bautismos solenes e solicitar a comversão dos gentios, os quais antes da sua vinda andavão já case persuadidos a se bautizarem, pola mais frequente converção dos mais que já tinhamos bautizados. Ficounos a nós emtão o cuidado [...] de os conservar, doutriná-llos e instrui-llos nas cousas da fee [...]. E vendo os Padres o que Sua Senhoria detriminava aserca da conversão, lhe deixarão tudo nas mãos asi como ho elle ordenou. ${ }^{5}$

O jesuíta Luís Fróis informou que o último batismo solene realizado pela Companhia de Jesus teria ocorrido em dezembro de 1560, com quatrocentas e nove pessoas batizadas. A partir de então, os interessados em adotar a fé católica "se remetião aos bauptismos do Arcebispo", conforme Fróis. Dois anos depois, Juan de Polanco afirmou que desde que D. Gaspar de Leão chegou à Índia "no solamento no há ayudado, mas aun há ympedido la conversión de los infieles, por no se concertar com nuestra Compañía". Polanco alegou que antes da proibição do arcebispo, os jesuítas teriam batizado vinte mil pessoas em Goa, mas depois "casi ninguno se há baptizado em aquella ínsula". ${ }^{6}$

O rei de Portugal reconheceu que os batismos solenes agradavam aos convertidos e, dada a exuberância e a qualidade dos padrinhos (costumavam ser os vice-reis), estimulavam os "infiéis" a se converterem. O soberano escreveu ao vice-rei D. Francisco de Coutinho (1561-1564) em seis de março de 1563, esperando que Coutinho resolvesse o dilema com o arcebispo D. Gaspar, levando em consideração que o "que mais importa ao bem da christandade [...] e dilatação de nossa sancta fee"7. Acerca da proibição sobre a realização dos batismos solenes, D. Gaspar a revogou (NAZARETH, 1887: 32).

D. Gaspar estabeleceu relações conflituosas com os jesuítas, ao passo que demonstrou sua simpatia pelos franciscanos, sobretudo pelo ramo da Mais Estreita Observância, pois pediu a renúncia do cargo de arcebispo para experimentar a 
vida contemplativa no convento franciscano da Madre de Deus de Goa (NAZARETH, 1887: 37).

Em virtude da renúncia de D. Gaspar, Frei Jorge Themudo governou o arcebispado de Goa entre 1568 e 1571. Contudo, Gaspar de Leão retornou à administração do arcebispado no período de 1574 a $1576^{8}$, convocou novamente os prelados para iniciar os trabalhos do $2^{\circ}$ Concílio Provincial de Goa (1575), interrompido devido à morte de Themudo ${ }^{9}$. D. Gaspar de Leão faleceu em 1576, após um novo retiro no convento franciscano mencionado, onde foi sepultado.

As reverberações do franciscanismo, sobretudo o componente místico e escatológico, podem ser encontradas em obras escritas por Gaspar de Leão, como o Desengano de perdidos, que redigiu durante o seu retiro espiritual no convento da Madre de Deus de Goa, pertencente à Ordem de São Francisco.

\section{A escrita do arcebispo: a carta para judeus e cristãos-novos}

D. Gaspar de Leão redigiu o "Tratado espiritual para o sacerdote quando diz missa e para os ouvintes [...] com hum suave exercício do nome de Jesus e Oração e meditação", publicado em Lisboa, em 1558. Em Goa, publicou o "Compêndio espiritual da vida cristã" (1561), destinado aos católicos da região, onde apresentou os princípios básicos da fé cristã em obra dividida em dois estados - o do pecado e da graça - e em quatro partes em que tratou da doutrina cristã, dos pecados, dos remédios contra eles e da oração e perfeição espiritual através de exercícios de devoção (MATOS, 1987: 41-72).

$\mathrm{O}$ arcebispo escreveu textos de polêmica antijudaica ou anti-islâmica, o que testifica a permanência dos antigos inimigos da fé católica existentes na Península Ibérica na imaginação política e religiosa de D.Gaspar. Esta permanência era reforçada diante da presença de cristãos-novos, judeus e muçulmanos na Ásia. 
Trataremos de dois escritos de D. Gaspar destinados a judaizantes e muçulmanos: a carta redigida para o Tratado que fez o mestre Hieronimo (1565) e o Desengano de Perdidos (1573). No primeiro escrito, D. Gaspar almejava tocar o coração de judeus e de cristãos-novos, cuja presença no Oriente foi o motivo do estabelecimento do Tribunal da Inquisição de Goa, em 1560. Desengano de perdidos teria mercadores, viajantes, sacerdotes, funcionários portugueses e goeses que adotaram a língua portuguesa como público leitor idealizado por D. Gaspar.

D. Gaspar escreveu a carta que precede a tradução portuguesa das obras do médico Josué Ibn Vives de Lorca, convertido ao cristianismo em 1412, que passou a se chamar Jerônimo de Santa Fé (HERMANN \& VAINFAS, 2005: 24). Poucos escritos deste teor antijudaico foram produzidos em Portugal antes do século XVI, tais como o Ajuda da Fé de Mestre Antônio, médico de João II, que escreveu seu livro quando se converteu em 1486, inspirado no texto de Jerônimo de Santa Fé. Em seguida, João de Barros escreveu Ropicapnefma (1531) e Diálogo evangélico sobre os artigos da fé contra o Talmude dos judeus (1542-45), o cisterciense Francisco Machado redigiu Espelho dos cristãos-novos e convertidos (1541), Diogo de Sá produziu a Inquisição e segredos da fé contra a obstinada perfídia dos judeus contra gentios e hereges, que não deve ter sido escrito antes de 1550 (TALMAGE, 1981: 267-268). Segundo Bruno Feitler (2005), a primeira produção antijudaica portuguesa não visou especificamente os judaizantes de Portugal, voltando-se especialmente para os povos de outras línguas e culturas no contexto da expansão portuguesa, como a carta de Gaspar de Leão que seria dirigida aos judeus da Índia ou como o Diálogo evangélico de João de Barros.

$\mathrm{Na}$ carta que antecede a tradução portuguesa do texto de Jerônimo de Santa Fé, D. Gaspar afirmou que a sua motivação para escrever seria a sua responsabilidade pastoral. Ao longo da carta, Gaspar de Leão descreveu a condição de judeus, como ovelhas enfermas, desprezadas, perdidas por mais de mil e quinhentos anos, apresentando o que julgava ser o motivo de tantas tribulações: 
lembrando-vos que nenhum cativeiro de vossos passados chegou a cento \& cincoenta annos, \& elle vosso passa de mil \& quinhentos [...] cuidando que o maior peccado dos peccados he a idolatria, pella qual foram castigados vossos anos em Babylonia per espaço de setenta annos: \& esse vosso castigo dura há mil seiscentos sem fazer idolatria? Que peccado pois será este, cuja rigorosa justiça persevera tanto tempo, senam negardes \& matardes o Rey Messias Iesu Christo?(LEÃO, 1565) ${ }^{10}$

D. Gaspar reforçava a idéia da rejeição de Cristo como Messias como razão da "villeza \& desprezo que padeceis", em contraste com "honra passada dos judeus". Esperando convencer seus leitores, atacou as supostas afirmações dos rabinos e a interpretação do talmude, especialmente acerca do Messias "ser já nascido, \& vindo ao mundo" no tempo da destruição do segundo templo de Jerusálem, "mas que ainda não apareceo", o que faz com que D. Gaspar denomine este Messias dos rabinos, sarcasticamente, "um menino de mais de mil \& quinhentos anos" (LEÃO, 1565). O arcebispo cita algumas explicações sobre o paradeiro dos falsos Messias: andava pelo mundo como um iogue, vivia em um lugar paradisíaco em companhia do profeta Elias ou habitava no monte Cáspio e agiria como um segundo Alexandre Magno, que venceria as nações com as armas. Menciona o rabino Moisés, filho de Levi, para quem o Messias estaria em Roma. D. Gaspar adiciona à crença sobre a vivência do Messias em Roma um sinistro final:

Dizem sonhando que o Messias se criara em Roma nos passos do Papa, do qual averá muytas honras, \& depois de assi favorecido, reqrerá ao Papa da parte de Deos que o deixei ir a Ierusalem \& nella ajuntar \& restituir judeus, \& por o Papa não querer, matará o Papa \& destruirá a Roma (LEÃO, 1565).

Para desacreditar os rabinos, D. Gaspar apresentava os equívocos na identificação do verdadeiro Messias, como no caso de um rei do Marrocos que andava "sobre um valente asno, ainda que mouro foy tido por Messias dos judeus daquele reino". 
Durante o reinado de D. João III teria aparecido Ribaldo chamado o judeu do sapato na Espanha - que afirmava ter vindo de onde estavam as tribos de Israel. Isto teria sido o suficiente, segundo D. Gaspar,

pera ser tido na Hespanha \& dos judeus de África por Messias [...]. Depois deste no mesmo reino hum sapateiro de Setuvel sem saberem de que tribu, só por falar muyto na sagrada escriptura, foy avido por Messias (LEÃO,1565).

No final da carta, o arcebispo apresenta o livro de Jerônimo de Santa Fé, cuja atitude é tratada como um exemplo, pois se tratava de um judeu convertido à fé católica. Reforça a sua obrigação de fornecer orientações espirituais, enquanto prelado, mesmo para aqueles que não se encontravam nos domínios portugueses do Oriente, como na Turquia, local que poderia estar fora da jurisdição do Arcebispado de Goa, "todavia não fora da obrigação, de trazer as ovelhas perdidas da casa de Israel, ao curral da ygreja Catholica" (LEÃO, 1565).

\section{Gaspar e as profecias sobre a destruição do islã}

A outra obra a ser analisada - o Desengano de Perdidos - é em um tratado que visa a conversão de mouros ao cristianismo, a apresentação das estratégias para adquirir a perfeição espiritual e exalta a "via unitiva". Na primeira parte do livro, D. Gaspar adotou a narrativa em forma de diálogo ${ }^{11}$ entre um cristão e um mouro (turco) para atacar o Corão e convencer a respeito da alegada superioridade do cristianismo, ou seja, esperava "desenganar" (conforme o título de sua obra), retirar os infiéis dos erros ensinados por Maomé.

A literatura de polêmica anti-islâmica pode ser identificada no diálogo sereno de Raimundo Lulio ou na forma escolástica de Pugio Fidei (ou o Puñal de la fe) de Raimundo Marti. Outros autores que demonstraram o mesmo pendor para atacar o islamismo foram São Pedro Pascoal (El obispo de Jean sobre la 
secta maometana), Juan de Torquemada (Defensorium fidei contra Iudaes, haereticos et sarracenos, 1473), Juan Andrés (Libro que se llama Confúsion de la secta mahometana y el Alcorán, de 1515). Bernardo Pérez de Chinchón escreveu o Libro llamado Antialcorano (Valencia, 1532) que trazia informações sobre os costumes dos mouros mal convertidos. Lope de Obrégon escreveu Confutación del Alcorán y la secta mahometana (Granada, 1555). Diogo de Castilho escreveu Origem dos turcos (Bélgica, 1538) onde profetizou a destruição dos turcos por Carlos V. Bernardo Pérez de Chinchón, Alonso de Madrigal el Tostado e Enrique Herp foram autores que influenciaram a escrita de D. Gaspar, conforme Eugenio Asensio na introdução de Desengano de perdidos.

Gaspar de Leão iniciou a escrita de Desengano de perdidos durante seu retiro espiritual no convento da Madre de Deus. O contexto da escrita era de certa euforia em virtude das vitórias referentes aos cercos de Goa e de Chaul e das informações sobre a vitória de Lepanto contra o "Turco". A conjuntura pode ter estimulado a crença de Gaspar de Leão em torno da destruição definitiva do islã, adicionada a sua interpretação peculiar do livro de Apocalipse. A razão para escrever a obra encontra-se no prólogo, onde Gaspar de Leão revelou a expectativa da vinda de homens e munições do reino para os combates no Estado da Índia travados em 1572 contra Idalcão e Nizamaluco. Apesar das vitórias, obtidas "graças a Deus", a frustração com a vida das naus, menos aparelhadas que no passado, deixou o Estado da Índia "em falta não pequena" e a

gente da terra novamente convertida, \& gente fraca desmaiaram em alguma maneira, por desarmarem em vão as esperanças, que tinhão concebido: \& desconsolados diziam, Está bom fazer Christão, \& entregar a Mouros? As quaes palavras sendo-me relatadas per hum religioso, verdadeiramente me moverão a fazer, \& escrever, nam livro, mas huma pregação pera consolação desta gente. (LEÃO, 1958: 10) 
Gaspar de Leão alegava que o Estado da Índia não carecia de socorro, pois já contava com a ajuda de Deus. Confiava na profecia de Apocalipse 18, onde D. Gaspar encontrou os indícios da iminente destruição total do islamismo, iniciada em outubro de 1570. O anjo mencionado na profecia seria o Papa Pio V, que governava a Igreja quando foi concluído o Concílio de Trento. A destruição seria conduzida pela Liga Santa, conduzida pelo Papa e por Felipe de Castela, "senhor da quarta parte do mundo descoberta" (LEÃO, 1958: 66-72). O rei D. Sebastião teria sido convencido pelo Papa, através do Cardeal Caraffa, que entrasse na Liga Santa e se casasse com a irmã do rei da França, após o persuadir a abandonar a aliança com o turco.

Gaspar de Leão acreditava ter encontrado referências à conversão dos gentios nas linhas do profeta Isaías (60:8): “Quem são estes que vêm voando como nuvens e como pombas, ao seu pombal". Gaspar de Leão apresentou o significado, que seria entrada da fé católica, pois comparou as naus dos navegantes ibéricos às nuvens da profecia e afirmava que as velas das naus pareciam pombas brancas quando vistas de longe, para reiterar a pertinência de sua interpretação. O trecho do versículo seguinte - "para que eu traga teus filhos de longe, sua prata e seu ouro" -, D. Gaspar associou aos gentios que são trazidos para fé católica, vindos de remotas distâncias.

Vemos que de todas as Ilhas, \& Arcepelago oriental, de Ceylão, até Japões, Iaoa, Maluco [...] vem cadanno as Náos carregadas das Drogas, ouro, \& prata, \& todos os mais bens daquellas ilhas, \& juntamente com esta fazenda os insulanos gentios, \& recebem a fé: $\mathrm{E}$ daquy vão as naus do Reyno carregadas das mesmas fazendas, \& muitos naturaes daquellas partes (LEÃO, 1958).

A segunda parte do Desengano de Perdidos trata de vícios e virtudes, com referências à alegoria das sereias e da galera da alma. As sereias representariam a sensualidade, os prazeres carnais, a sedução, enquanto o herói grego Ulisses - que escapa de naufrágios por não se deixar seduzir - simboliza o bom cristão que despreza tudo o que não se origina no espírito. A 
galera da alma seria a Igreja. O destinatário desta segunda parte, um tratado moral, não seria tanto o mouro, mas o cristão recém-convertido ou o cristão que adota a fé católica há tempos, mas não segue os preceitos evangélicos. O diálogo deixa de ser entre um cristão e um mouro, mas entre um mestre e um discípulo (GANHO, 2000: 329 - 331).

A terceira parte do livro dedica-se à via "unitiva" (busca da união mística do fiel com Deus), que seria a "via do coração", do amor, contrapondo à "via escolástica" (a via da ciência, da inteligência, do entendimento). A via de amor preconizada por frei Gaspar de Leão não exaltava o papel das letras no processo de conversão, mas a realização de si-mesmo como imago dei, alcançada pela oração e pela mortificação, pela caridade e pela pobreza (XAVIER: 2003, 357).

A terceira parte tem como fonte principal Henrique Herp, franciscano que morreu em 1477 e escreveu Espelho de perfeição. D. Gaspar menciona a existência de duas vias que conduzem a Deus: a comum ou escolástica privilegia o conhecimento e a razão, ao passo que a via secreta ou a mística teologia e de amor unitivo concede espaço ao coração e à vontade (GANHO, 2000: 331). A mística estaria associada a experiências de natureza religiosa ou religioso-filosófica, que se desenvolve em um plano que não estaria aquém, mas além da razão, apontando para uma realidade transcendente, em que o homem pode ser elevado às formas mais altas de amor e de conhecimento que é possível atingir nessa vida (VAZ, 2000: 9-10). A mística portuguesa se revelaria em uma via de amor a Deus e em obras de caridade, em missões entre os homens. O coração seria o órgão privilegiado do conhecimento, pois Deus seria atingido através do amor (COSTA, 1986: 60-68).

Em Desengano de Perdidos, as reverberações do franciscanismo são perceptíveis. Enquanto os teólogos dominicanos refletiam sobre a experiência imperial ibérica a partir de uma concepção eclesiástica e jurídica da conquista, recorrendo ao direito romano, ao direito canônico e à lógica aristotélica, os franciscanos apresentaram uma compreensão mística da conquista. A concepção franciscana era apocalíptica, 
messiânica, com raízes na mística dos Espirituais franciscanos (marcados pelo pensamento de Joaquim de Fiore) e pelo ideal da Reforma da Observância (PHELAN, 1970: 109).

Os franciscanos da Mais Estreita Observância, que despertaram a admiração de Gaspar de Leão, desenvolveram uma teologia universal que tentava penetrar e organizar o Mistério da eternidade revelado no tempo e no espaço deste mundo terrestre (COSTA, 1986). Para compreender os grandes eventos do mundo (a expansão ibérica, a conquista das almas), os franciscanos utilizavam o método de exegese bíblica baseado na analogia, na convicção de que as palavras das Sagradas Escrituras, sob a inspiração do Espírito Santo, poderiam revelar verdades que escapariam à razão humana. O conhecimento poderia ser obtido através da investigação dos significados subjacentes às personagens, aos episódios e aos objetos referidos na Bíblia.

Este tipo de exegese encontra-se no Desengano de perdidos. A narrativa de D. Gaspar uniu conquista e expansão do Evangelho, amparada em vaticínios apocalípticos. Os franciscanos influenciados por Joachim de Fiore consideravam que a propagação do Evangelho nos confins do mundo seria um presságio da proximidade do fim dos tempos, precedido por maravilhas como a recuperação de Jerusalém, a conversão definitiva de mouros e judeus. Na política, surgiria um papa angélico e um rei imperador virtuoso. Mas a versão crua deste joaquimismo não se desenvolveu em Portugal, nem em D. Gaspar, pois era inexistente a grande oposição entre a Igreja carnal de Roma e a Igreja espiritual dos monges. O profetismo joaquimista adaptou-se ao contexto da Contra-Reforma, quando os traços anti-romanos desapareceram: em D. Gaspar, o anjo anunciado é o papa. Esta é a paisagem religiosa e cultural do arcebispo de Goa, no período da vitória de Lepanto ${ }^{12}$. 


\section{Considerações finais}

O místico D. Gaspar de Leão revelou em seus escritos que carregava o imaginário religioso e político construído em sua vivência na Península Ibérica, pois identificava em muçulmanos e judeus uma possível ameaça à pureza da fé católica. Como Arcebispo de Goa, deparou-se com a migração de judeus e de cristãos-novos para o Oriente, estimulados a escapar das perseguições realizadas na Espanha e em Portugal. Gaspar de Leão reconhecia a instabilidade dos domínios portugueses no Oriente, em virtude da influência e do poder de chefes políticos muçulmanos. Mesmo Goa, a chamada "Roma do Oriente", possuía reinos islâmicos em suas imediações.

As práticas e as idéias redigidas por Gaspar de Leão indicam uma multiplicidade de influências. Como Arcebispo de Goa, atuou em um momento em o modelo de bispo concebido no Concílio de Trento (PAIVA, 2006: 132-133) ressaltava o seu empenho pessoal no governo, a residência na diocese de Goa, o cuidado com o comportamento do clero, a considerável atividade legislativa através da realização de sínodos e de constituições (como os dois primeiros concílios provinciais de Goa, conduzidos por D. Gaspar), o recurso a visitas pastorais para correção da postura do clero e dos fiéis (o que realizou em 1564 e 1574). Os decretos tridentinos apresentavam o bispo como um pastor e D. Gaspar explicou que o motivo da redação da carta - que precedia a tradução da obra de Jerônimo de Santa Fé - seria a sua obrigação pastoral.

Outro aspecto que comporia o perfil episcopal concebido no Concílio de Trento seria a necessidade do bispo agir como um exemplo de vida cristã, de humildade e modéstia (PAIVA, 2006: 133). Nesse sentido, outra matriz de pensamento imbricou-se na formação do ideal de prelado que D. Gaspar procurou representar, o franciscanismo radical da Mais Estreita Observância, pautado em preocupações ascéticas através do rigor da penitência, da pobreza evangélica e da elevação mística (DIAS, 1986: 145). D. Gaspar pediu o afastamento do cargo de arcebispo para se retirar no convento franciscano, dedicando-se 
à elevação espiritual, a orações. Reagiu aos modelos missionários que pareciam se afastar da humildade e da pobreza evangélica, rejeitando os batismos solenes conduzidos pelos jesuítas.

Gaspar de Leão realizou uma apropriação peculiar da dimensão escatológica e profética do franciscanismo a partir do contexto histórico em que atuou como arcebispo e que elaborou os seus escritos. Na década de 1570, a mesma década da publicação do Desengano de perdidos, a política do rei D. Sebastião sofria uma inflexão em favor das investidas portuguesas no norte da África, local tradicionalmente visto como um prolongamento da guerra de reconquista contra os muçulmanos (HERMANN, 1998: 89-95). Em sua última obra escrita, Gaspar de Leão revelou o otimismo diante da conjuntura aparentemente auspiciosa, em virtude da vitória contra os turcos em Lepanto e dos possíveis êxitos contra reis muçulmanos que ameaçavam os territórios portugueses do Estado da Índia. Gaspar de Leão vinculou o momento histórico da expansão portuguesa ao período em que os gentios e "infiéis" se converteriam definitivamente ao catolicismo, unindo profecia e história em sua retórica. Como não testemunhou o triplo malogro de 1578 (a perda da batalha de Alcácer-Quibir, da vida do rei D. Sebastião e da independência política do reino de Portugal) por ter falecido em 1576, D. Gaspar forneceu, em seu último livro, uma visão otimista acerca das conquistas militares portuguesas e do avanço da cristandade contra o islã.

\section{REFERÊNCIAS BIBLIOGRÁFICAS}

ALDEN, Dauril. The making of an enterprise: the Society of Jesus, its empire, and beyond, 1540-1750. Stanford: Stanford University Press, 1996.

ARANHA, Paolo. Il cristianesimo latino in India nel XVI secolo. Milano: FrancoAngeli, 2006. 
ARIENZO, Valdo d'. "La missione di um mistico: Dom Gaspar de Leão primo arcivescovo di Goa" In Studi e Ricerche sull'Oriente Cristiano. Roma, Anno X, Fasc. 1, gennaio-aprile, p. 19- 36 e p.113- 135, 1987.

BOSCHI, Caio. "Estruturas Eclesiásticas e Inquisição" In: BETHENCOURT \& CHAUDHURI. História da expansão portuguesa. Navarra: Círculo de Leitores e Letras, 1998, vol. II, pp.429-452.

COSTA, Dalila L. Pereira da Costa. Místicos portugueses do século XVI. Porto: Lello \& Irmão, 1986.

COSTA, João Paulo Oliveira e. "A diáspora missionária" in Carlos Moreira Azevedo (dir.). História religiosa de Portugal, 3 vols., Lisboa, Círculo dos Leitores, vol. 2, 2000, pp. 255-313.

COUTINHO, Fortunato. Le régime paroissial des dioceses de rite latin de I'Inde des origines (XVIe siecle) à nous jours. Louvain: Publications Universitaires de Louvain, 1958.

DIAS, J. S. da Silva. Influencia de los descubrimientos en la vida cultural del siglo XVI. México. Fondo de Cultura Económica, 1986.

DORÉ, Andréa. Cristãos na Índia no século XVI: a presença portuguesa e os viajantes italianos. Revista Brasileira de História,São Paulo, v. 22, n. 44, pp. 311-339, 2002.

FEITLER, Bruno. O catolicismo como ideal: produção literária antijudaica no mundo português da Idade Moderna. Revista Novos Estudos, n.72, p.137-158, 2005.

GANHO, Maria de Lourdes Sirgado. "A obra Desengano de Perdidos de D. Gaspar de Leão" In: GONÇALVES, Nuno da Silva Gonçalves (Coord.). A Companhia de Jesus e a missionação no Oriente. Lisboa: Brotéria/Fundação Oriente, 2000, p. 325-334.

HERMANN, J. No reino do desejado. São Paulo: Companhia das Letras, 1998.

\& VAINFAS, Ronaldo. Judeus e conversos na Ibéria do século XV: sefardismos, heresias, messianismo. In: GRINBERG, Keila. (Org.). História dos Judeus no Brasil. Rio de Janeiro: Civilização Brasileira, 2005, p. 15-41.

LEÃO, Gaspar de. Desengano de Perdidos, feito pêra glória de Deus e consolação dos nouamente convertidos, \& fracos na fé, \& pêra proveito dos que querem deixar os pecados, \& seguir as virtudes; \& o caminho da perfeição do amor divino (Goa, 1573). Coimbra: Acta Universitatis Conimbrigensis, 1958.

. Tratado que fez mestre Hieronimo medico do papa Benedicto 13 cõtra os iudeus... Carta do primeiro arcebispo de Goa ao pouo de 
Israel seguidor ainda da ley de Moises \& do Talmud por engano \& malicia dos seus Rabis. Em Goa : por Ioão de Endem, 1565.

MATOS, M. C. de. Humanismo e evangelização no Oriente no século XVI. Revista ICALP, v.7-8, pp. 41-72, 1987.

MENDONÇA, Delio de. Conversions and citizenry: Goa under Portugal. 1510-1610. New Delhi: Concep Pub., 2002.

NAZARETH, Casimiro Cristovam. Mitras lusitanas no oriente : catálogo chronologico-historico dos prelados da egreja metropolitana de Goa e das dioceses suffraganeas, com a recopilação das ordenanças por eles emitidas, e sumário dos factos notáveis da história eclesiástica de Goa. Nova Goa : Imprensa Nacional, 1887.

NEWITT, M. Formal and Informal Empire in the History of Portugueses Expansion In: Portugueses Studies, n.17, p. 1-22, 2001.

PALOMO, Federico. Disciplina christiana»:Apuntes historiográficos en torno a la disciplina y el disciplinamiento social como categorías de la historia religiosa de la alta edad moderna. Cuadernos de Historia Moderna. Madrid, no. 18, p.11-138, 1997.

PHELAN, John Leddy. The millenial kingdom of the Franciscans in the New World. Berkely \& Los Angeles: University of California Press, 1970. REGO, A . Silva. Documentos para História das Missões do Padroado Português no Oriente. Lisboa: Fundação Oriente/Comissão Nacional para as Comemorações dos Descobrimentos Portugueses, 1991-1996, $12 \mathrm{v}$.

RUSSELL-WOOD. Fronteiras de integração In: BETHENCOURT \& CHAUDHURI. História da Expansão Portuguesa. Navarra: Círculo de Leitores, 1998, v. 1, PP.238-255.

SANTOS, Catarina Madeira. Goa é a chave de toda a Índia: Perfil político da capital do Estado da Índia (1505-1570). Lisboa: CNCDP, 1999.

TALMAGE, F. To sabbatize in peace: jews and new christians in sixteenth-century portuguese polemics. Harvard Theological Review, vol. 74. n.3, pp.265-285, 1981.

THOMAZ, Luiz Filipe. De Ceuta a Timor. Lisboa: Ed. Difel, 1994.

VAZ, Henrique C. de Lima . Experiência mística e filosofia na tradição ocidental. São Paulo: Loyola, 2000.

VENTURA, Ricardo. Estratégias de conversão ao tempo de D. Gaspar de Leão, $1^{\circ}$ Arcebispo de Goa: reconstituição histórica de uma controvérsia. In: COLÓOUIO INTERNACIONAL A COMPANHIA DE JESUS NA PENÍNSULA IBÉRICA NOS SÉCULOS XVI E XVII, 2004. 
Actas... Porto, Instituto de Cultura Portuguesa da Faculdade de Letras da Universidade do Porto, 2005, vol. II, pp. 505-517.

VERNARD, MAYEUR, PIETRI \& VAUCHEZ (org.). Histoire $d u$ christianisme. Paris. Desclée, 1992, v.8.

WICKI, Joseph S. J., Documenta Indica, Roma, M. H. Societatis Iesu, 1948-1988, 18v.

XAVIER, Ângela Barreto. A invenção de Goa: Poder imperial e conversões culturais nos séculos XVI e XVII. Florença, 2003.Tese (doutorado em História). Instituto Universitário Europeu.

FARIA, Patricia Souza de. Reform and prophecy: the activity of D. Gaspar de Leão, the Archbishop of Goa and mystic. História, v.28, n.1, p.145-168, 2009.

Abstract: A study of the first Archbishop of Goa, D. Gaspar de Leão (1560 - 1576), who played a significant role in the Christianization process of the Portuguese-controlled lands in Asia. During this period D. Gaspar administrated the Archbishopric of Goa, the Goa Inquisition (the sole inquisitorial court instituted in a Portuguese domain) was created, the first Provincial Council in the region was founded in 1567, and the Constitutions of the Archbishopric of Goa were drawn up, in consonance with the Council of Trent's resolutions. All of which motivated the formation of provincial synods and the work of the bishops in carrying out a spiritual reform among the clergy and the faithful. D. Gaspar was influenced by mystic Christian tendencies and published works about the mystical union or the expansion of Evangelism, replete with prophecies concerning the final conversion of Muslims and Jews.

Keywords: Portuguese Empire, India, Catholicism.

\section{NOTAS}

${ }^{1}$ Documento 62, extraído do volume 5 da coleção: REGO, A. Silva. Documentos para História das Missões do Padroado Português no Oriente. Lisboa: Fundação Oriente/Comissão Nacional para as 
Comemorações dos Descobrimentos Portugueses, 1991-1996, $12 \mathrm{v}$. Adiante, citar-se-á: DHMPPO.

${ }^{2}$ DHMPPO, v. 10, doc. 44, p.337-338; Ver o documento 90, extraído do volume 7 organizado por: WICKI, Joseph S. J., Documenta Indica, Roma, M. H. Societatis Iesu, 1948-1988, 18v. Adiante, citar-se-á: DI.

${ }^{3}$ DHMPPO, v. 10, doc.54, pp.481-800.

${ }^{4}$ DI, v.5, doc.43, pp.272 e 276.

${ }^{5}$ DI, v.5, doc.43,pp.272-3. No dia do batismo solene era organizada uma grande procissão no colégio de Goa, com grande pompa, em que participam as autoridades civis e eclesiásticas; os meninos traziam os cabelos enfeitados com flores e empunhavam ramos; os catecúmenos ficavam em casa e ao passar a procissão eram conduzidos à ela, depois seguiam para a igreja.

${ }^{6}$ DI, v.5, doc.81, p. 554-555. Ver : doc. 85 e 94.

${ }^{7}$ Biblioteca Nacional de Lisboa, códice 176, Memórias para a História Ecclesiástica do Arcebispado de Goa e seus suffragâneos. Microfilme F. 2527; DI, v.6, doc.4 A, p.12-13.

${ }^{8}$ DI, v.8,doc.2, p. 42.

${ }^{9}$ Esse concílio tratou de matérias ligadas ao culto divino, ao aumento da fé, à prevenção dos relapsos, à reforma dos costumes; os hindus foram proibidos de usar palanquins, andar a cavalo e deveriam ser substituídos por cristãos na coleta de rendas da Coroa.

${ }^{10}$ A carta escrita por Gaspar de Leão não foi originalmente numerada.

${ }^{11}$ Exemplos de autores que escreveram em forma de diálogo no século XVI: João de Barros, Francisco de Holanda, Samuel Usque, Garcia da Orta.

${ }^{12}$ Introdução de Eugenio Asensio para a obra: LEÃO, Gaspar de. Desengano de Perdidos (1573). Acta Universitatis Conimbrigensis, 1958, p.V - CIX.

Artigo recebido em 03/2009. Aprovado em 06/2009 